\title{
Proximate composition and antioxidant activity of Syzygium cumini fruit grown at different regions in Bangladesh
}

\author{
1,* Ahmed, S., ${ }^{2}$ Ahmed, K.S., ${ }^{3}$ Hossain, M.S., ${ }^{4}$ Azam, M.S., ${ }^{3}$ Rahman, M. and ${ }^{3}$ Hoque, M.M. \\ ${ }^{1}$ Department of Agro Product Processing Technology, Jashore University of Science and Technology, \\ Jashore-7408, Bangladesh \\ ${ }^{2}$ Chemical Research Division, BCSIR Laboratories Dhaka, Bangladesh Council of Scientific and Industrial \\ Research (BCSIR), Dhaka-1205, Bangladesh \\ ${ }^{3}$ Department of Food Engineering and Tea Technology, Shahjalal University of Science and Technology, \\ Sylhet-3114, Bangladesh \\ ${ }^{4}$ CAS Key Laboratory of Nutrition, Metabolism and Food Safety, Shanghai Institute of Nutrition and Health, \\ University of Chinese Academy of Sciences, 200031, Shanghai, PR China
}

\section{Article history:}

Received: 13 April 2020

Received in revised form: 15

May 2020

Accepted: 15 May 2020

Available Online: 16 June 2020

\section{Keywords:}

Syzygium cumini,

Antioxidant activity,

Proximate composition,

Reducing power

DOI:

https://doi.org/10.26656/fr.2017.4(5).162

\begin{abstract}
The risk of degenerative diseases decreases with the consumption of high antioxidant containing fruits. This study aimed to analyze the proximate composition and antioxidant activity of pulp and seed of Syzygium cumini. Proximate composition was determined by following the AOAC method. Minerals and heavy metals were analyzed using a flame photometer and an atomic absorption spectrometer. In-vitro antioxidant activity was evaluated by using phosphomolybdenum, ferrous ion chelating ability assay and reducing power assay methods. In proximate composition analysis pulp contained significantly $(p<0.05)$ greater amount of minerals than seed but seed contained a higher amount of protein and lipid than pulp. In the bioactive compound analysis, seed extracts possessed significantly $(\mathrm{p}<0.05)$ greater amount of Chlorophyll A, Chlorophyll B and total carotenoids. Additionally, seed extracts exhibited significantly $(p<0.05)$ more total antioxidant capacity, reducing power and ferrous ion chelating ability compared to pulp extracts. This study revealed that the seed of Syzygium cumini contains significantly $(p<0.05)$ higher amount of minerals, bioactive compounds and showed better antioxidant property. Therefore, Syzygium cumini seed can be a potential source of natural antioxidant in medicine and food production.
\end{abstract}

\section{Introduction}

Nowadays, consumers are getting more interested in taking functional foods (Savikin et al., 2009). Some specific compounds in food are correlated to the functionality of that food. Among them, the antioxidant family is the most studied functional group. The consumption of fruits high in antioxidants is reported to reduce the risk of cancer, inflammation and cardiovascular disease (Leong and Shui, 2002). Fruits are rich in different antioxidants like phenolic compounds, tannins, anthocyanins, carotenoids, flavonoids, etc (Leong and Shui, 2002).

Syzygium cumini is commonly known as a black plum in English and 'Jaam' in Bengali. It is widely found in the subcontinent of Asia and other tropical countries. The fruit pulp is sweet and seeds are acrid, sour and tonic. The pulp is rich in different nutrients and has potassium, sodium, phosphorous, calcium, zinc and iron those are very important minerals and some vitamins like thiamine, niacin, carotenoids and ascorbic acid. (Noomrio and Dahot, 1996). The fruit is very well known for its pharmacological properties since ancient age. In an extensive review, Baliga et al. (2011) explained that $S$. cumini has many pharmacological characteristics like antibacterial, antiviral, antifungal, anti-diarrheal, free radical scavenging, radioprotective, anti-inflammatory, anti-allergic, gastroprotective, cardioprotective, hypoglycemic and hypolipidemic. Nevertheless, it is widely used for anti-diabetic properties (Teixeira et al., 2000; Benherlal and Arumughan, 2007; Gordon et al., 2011). Vinegar is often produced from the juice of unripened fruit and jams, jellies, squashes, chutney, and wine are produced by 
using the ripened one (Zhang and Lin, 2009). Moreover, the seed of Jam has various use in Unani, Ayurveda and Chinese medicine to heal different diseases and disorders like digestive ailments. Several studies have focused on the bioactive compounds and antioxidant capacity of Jaam, but very few of them describe the properties of pulp and seed of this fruit separately. Hence, an effort has been made in this study to assess the proximate composition and antioxidant activity of pulp and seed of S. cumini fruit.

\section{Materials and methods}

\subsection{Sample collection}

Some fresh, as well as fully mature $S$. cumini (Jaam), was collected from Faridpur and Manikganj (Bangladesh). Considering the absence of visible damages and infection, uniformity in size and color fruits were selected and then those were kept in frozen $\left(-20^{\circ} \mathrm{C}\right)$ condition until laboratory analysis.

\subsection{Sample extraction}

The Pulp of $S$. cumini fruits were separated from the seed and freeze-dried at $-50^{\circ} \mathrm{C}$ and 0.001 mbar pressure. The seeds were dried in the oven at $40^{\circ} \mathrm{C}$. After the material was completely dry, it was pulverized in a knife grinder and kept at $-20^{\circ} \mathrm{C}$ for further analysis. The dried, ground sample $(200 \mathrm{~g})$ was dissolved into $800 \mathrm{~mL}$ of methanol/water $(80: 20, \mathrm{v} / \mathrm{v})$ and thoroughly mixed and shaken at room temperature $\left(22-25^{\circ} \mathrm{C}\right)$ using an orbital shaker for $48 \mathrm{hrs}$ and then filtered in a Buchner funnel. The thick residue was then subjected to re-extract for three times in the same way to maximize the extract. The filtrates were concentrated in a vacuum rotary-evaporator (model no. R-205, Switzerland). The concentrated filtrates were lyophilized and kept in an amber bottle at $20^{\circ} \mathrm{C}$ prior to further analysis.

\subsection{Analysis of proximate composition}

The amount of moisture in the sample was determined by AOAC (1990). The ash content was measured by Ranganna (1986). The percentage of protein in the samples was determined by Kjeldal method (AOAC, 2005). Fat content in the samples was evaluated by standard (AOAC, 2005) method.

Flame Photometer was used to determine Sodium and Potassium (Ward and Johnston, 1962). Flame Atomic Absorption Spectrometric (AAS) method was used to estimate Chromium, Cadmium, Nickel, and Lead (Atomic Absorption Spectrometer Thermo-Scientific Ice 3000 series), AOAC method (AOAC, 2005) is followed for AAS.

\subsection{Determination of total carotenoids and chlorophyll $A$ and $B$}

Total carotenoids and chlorophyll A and chlorophyll $\mathrm{B}$ were measured by following the procedure demonstrated by Dere et al. (1998) with minor modification. Five grams of extracts were added to 30 $\mathrm{mL} 85 \%$ acetone in an amber-colored reagent bottle. Leave them at room temperature to stand for approximately 20 hours. Extracts were filtered into 100 $\mathrm{mL}$ volumetric flax through glass wool and then made up to the volume by $85 \%$ acetone solution. The absorbance, against a blank sample ( $85 \%$ acetone), of the solution was read using a UV-VIS spectrophotometer at 470, 645 and $662 \mathrm{~nm}$. Following equation was followed to calculate chlorophyll $\mathrm{A}$ and $\mathrm{B}$ and total carotenoids: Chlorophyll A, $\mathrm{C}_{\mathrm{A}}(\mathrm{mg} / \mathrm{mL})=(\mathrm{A} 662 \times 11.75)-(\mathrm{A} 645 \times$ 2.350), Chlorophyll B, $C_{B}(\mathrm{mg} / \mathrm{mL})=(A 645 \times 18.61)-$ $(\mathrm{A} 662 \times 3.96)$, Total carotenoids $(\mathrm{mg} / \mathrm{mL})=(\mathrm{A} 470 \times$ $1000)-\left(\mathrm{C}_{\mathrm{A}} \times 2.27\right)-\left\{\left(81.4 \times \mathrm{C}_{\mathrm{B}}\right) / 230\right\}$

\subsection{Antioxidant activity determination}

\subsubsection{Phosphomolybdenum assay}

Total antioxidant capacity was assessed according to the phosphomolybdenum assay (Prieto et al., 1999). In brief, the extract reduces Molybdenum (VI) to Molybdenum (V) by forming phosphate-Molybdenum (V) complex which is green in color in acidic conditions. Reagent solution was made by mixing $28 \mathrm{mM}$ trisodium phosphate with $4 \mathrm{mM}$ ammonium molybdate and $0.6 \mathrm{M}$ sulfuric acid at a ratio of $2: 4: 4$. About $3 \mathrm{~mL}$ reagent solution was added with $0.3 \mathrm{~mL}$ sample $(1 \mathrm{mg} / \mathrm{mL})$ and kept in an incubator at $95^{\circ} \mathrm{C}$ for $90 \mathrm{~min}$. After cooling at normal temperature $\left(22\right.$ to $\left.25^{\circ} \mathrm{C}\right)$, the absorbance was taken at $695 \mathrm{~nm}$. We calculated the total antioxidant capacity in units of mg ascorbic acid equivalent (AAE).

\subsubsection{Reducing power assay}

The method described by Oyaizu (1986) with some modification was followed to measure the reducing power of fruit extracts. Various concentrations of the sample $(1 \mathrm{~mL})$ was added with $2.5 \mathrm{~mL}$ phosphate buffer $(0.2 \mathrm{M}$ and $\mathrm{pH} 6.6)$ and $2.5 \mathrm{~mL}$ of $1 \%$ potassium ferricyanide and warmed in a water bath at $50^{\circ} \mathrm{C}$ for 20 mins. The mixture was cooled at room temperature (22$25^{\circ} \mathrm{C}$ ) and mixed with $2.5 \mathrm{~mL} 10 \%$ trichloroacetic acid. The subsequent solution was centrifuged at $3000 \mathrm{rpm}$ for 10 mins. The supernatant $(2.5 \mathrm{~mL})$ was then added to 2.5 $\mathrm{mL}$ distilled water and $0.5 \mathrm{~mL}$ freshly prepared $0.1 \%$ ferric chloride solution, and the mixture was preserved for $10 \mathrm{~min}$ to complete the reaction properly. Reducing power was measured by taking the absorbance at 700 $\mathrm{nm}$. Different concentration of ascorbic acid was taken as standard. Higher the absorbance of the solution 
indicates greater reducing power of the extracts.

\subsubsection{Ferrous ion $\left(\mathrm{Fe}^{2+}\right)$ chelating ability assay}

Ferrous ion chelating ability of Syzygium cumini fruit extracts was measured following the procedure of Decker and Welch (1990). In brief, $5 \mathrm{~mL}$ of each extract at various concentrations were mixed with $0.1 \mathrm{~mL}$ of 2 $\mathrm{mM}$ concentration of $\mathrm{FeCl}_{2} .4 \mathrm{H}_{2} \mathrm{O}$ solution and $0.2 \mathrm{~mL}$ of $5 \mathrm{mM}$ ferrozine solution. The solution was mixed by vortex mixture and left for 10 mins at normal temperature $\left(22^{\circ} \mathrm{C}-25^{\circ} \mathrm{C}\right)$ for the proper reaction. The absorbance of the solution at $562 \mathrm{~nm}$ was taken with a double beam Scientific UV-Visible Spectrophotometer (Model, Analytic Jena Specord 205) against a blank. The control solution was prepared by all reagents except plant extracts. The percentage of inhibition was determined by the subsequent equation:

$$
\% \text { of inhibition }(\% \mathrm{I})=\frac{A_{0}-A}{A_{0}} \times 100
$$

Where, $\mathrm{A}_{0}$ denotes the absorbance of the control solution, and A denotes the absorbance of the solution containing plant extract.

\subsection{Statistical analysis}

Every chemical analysis was worked out in triplicate and the findings were articulated as means \pm standard deviations (SD). The analysis was done with the SPSS software, version 21. One way analysis of variance (ANOVA) according to the Bonferroni test was performed to compare the quantified variables.

\section{Results and discussion}

\subsection{Proximate composition of Syzygium cumini}

The proximate composition of pulp and seed of $S$. cumini is summarized in Table 1 . The pulp of S. cumini contained $85.94 \%$ and $90.95 \%$ moisture and seed contained $49.50 \%$ and $53.49 \%$ moisture. Noomrio and Dahot (1996) reported lower moisture content in the edible portion of $S$. cumini. Total ash content was significantly greater $(\mathrm{p}<0.05)$ in pulp than in the seed. The highest percentage of ash $(2.77 \%)$ content was found in PM. Based on the result, the pulp of both samples had lower protein content $(4.38 \%)$ compared to seed $(6.57 \%)$. Similar results were reported by Akhtar et al. (2016). The seed also contained a higher amount of fat than pulp. The fat content of seed varied from $0.62 \%$ to $0.79 \%$ whereas the fat content of pulp was within the range of $0.32 \%$ to $0.40 \%$.

For good health and proper function of the body, minerals play a very important role (Ho et al., 2012). Pulp contained a higher amount of sodium $(\mathrm{Na})$ and potassium (K) than the seed of $S$. cumini. K was the predominant mineral both in pulp and seed (Table 2). The highest content of $\mathrm{Na}$ and $\mathrm{K}$ were found in the sample PF. Sodium and potassium variability of fruits sometimes relies on soil type and meteorological conditions in the area where the fruit was cultivated. There were some elements such as lead and nickel that were not detected in the experimental samples, thus making the fruits safer for consumption. The results obtained showed that pulp contains a higher amount of mineral than the seed of $S$. cumini.

Phenolic compounds, ascorbic acid, and carotenoids are the main antioxidant substances that are found in plants and fruits (Savikin et al., 2009). Electron-rich double bonds and hydroxyl groups in the structure of compounds are mainly responsible for their antioxidant properties. The results for total carotenoids, chlorophyll A and chlorophyll B was exemplified in Table 3. Carotenoids are generally recognized as precursors of vitamin A, but it also demonstrates a remarkable level of antioxidant activity. The pulp and seed of Jaam contained carotenoids in the range from $6.6204 \mathrm{mg} / \mathrm{g}$ dry extract to $39.3682 \mathrm{mg} / \mathrm{g}$ dry extract. In another study, Rufino et al. (2011) found $0.51 \mathrm{mg} / 100 \mathrm{~g} \mathrm{FW}$ carotenoids in $S$. cumini. Chlorophyll A values were between 0.023 and $0.1650 \mathrm{mg} / \mathrm{g}$ dry extract, Chlorophyll B was ranged from 0.0324 to $0.0718 \mathrm{mg} / \mathrm{g}$ dry extract. It was observed that significantly higher $(\mathrm{p}<0.05)$ amount of chlorophyll A, chlorophyll B, and total carotenoids was found in the seed in comparison with the pulp extract of S. cumini and the highest amount of chlorophyll A, chlorophyll B, and total carotenoids were found in SM. Total carotenoids, Chlorophyll A and Chlorophyll B in pulp and seed of S. cumini collected from Manikganj were higher than the $S$. cumini collected

Table 1. Proximate composition of S. cumini (dry matter)

\begin{tabular}{ccccc}
\hline Nutritional composition (\%) & PF & SF & PM & SM \\
\hline Moisture (fresh matter) & $85.94 \pm 2.27^{\mathrm{a}}$ & $53.49 \pm 1.17^{\mathrm{b}}$ & $90.95 \pm 2.20^{\mathrm{a}}$ & $49.5 \pm 1.31^{\mathrm{b}}$ \\
Ash & $2.74 \pm 0.10^{\mathrm{a}}$ & $2.09 \pm 0.08^{\mathrm{b}}$ & $2.77 \pm 0.11^{\mathrm{a}}$ & $1.83 \pm 0.06^{\mathrm{c}}$ \\
Protein & $4.37 \pm 0.91^{\mathrm{a}}$ & $6.56 \pm 0.82^{\mathrm{a}}$ & $4.38 \pm 0.90^{\mathrm{a}}$ & $6.57 \pm 0.71^{\mathrm{a}}$ \\
Lipids & $0.4 \pm 0.09^{\mathrm{a}}$ & $0.79 \pm 0.11^{\mathrm{b}}$ & $0.32 \pm 0.06^{\mathrm{a}}$ & $0.62 \pm 0.08^{\mathrm{ab}}$
\end{tabular}

Values are presented as mean $\pm \mathrm{SD} ;(\mathrm{n}=3)$. Means with different superscript letters within the row differ significantly at $\mathrm{P}<0.05$. PF: Pulp of $S$. cumini collected from Faridpur, SF: Seed of S. cumini collected from Faridpur, PM: Pulp of S. cumini collected from Manikganj, SM: Seed of $S$. cumini collected from Manikganj. 
Table 2. Minerals and heavy metals content of S. cumini

\begin{tabular}{cccccc}
\hline \multicolumn{2}{c}{$\begin{array}{c}\text { Minerals and Heavy metals } \\
\text { (mg/100g dry sample) }\end{array}$} & $\mathrm{PF}$ & $\mathrm{SF}$ & $\mathrm{PM}$ & $\mathrm{SM}$ \\
\hline \multirow{2}{*}{ Minerals } & $\mathrm{Na}$ & $11.37 \pm 0.21$ & $6.89 \pm 0.15$ & $10.68 \pm 0.24$ & $8.96 \pm 0.13$ \\
& $\mathrm{~K}$ & $889.88 \pm 50$ & $517.72 \pm 45$ & $856.69 \pm 68$ & $514.25 \pm 35$ \\
\hline \multirow{4}{*}{ Heavy metals } & $\mathrm{Cr}$ & $\mathrm{BDL}$ & $0.046 \pm 0.007$ & $0.225 \pm 0.05$ & $0.456 \pm 0.06$ \\
& $\mathrm{Cd}$ & $0.075 \pm 0.01$ & $0.035 \pm 0.008$ & $0.073 \pm 0.01$ & $0.052 \pm 0.009$ \\
& $\mathrm{Ni}$ & $\mathrm{BDL}$ & $0.923 \pm 0.08$ & $\mathrm{BDL}$ & $\mathrm{BDL}$ \\
& $\mathrm{Pb}$ & $\mathrm{BDL}$ & $\mathrm{BDL}$ & $\mathrm{BDL}$ & $\mathrm{BDL}$ \\
\hline
\end{tabular}

Values are expressed as mean $\pm \mathrm{SD}$; $(\mathrm{n}=3)$, BDL: Below detection level

Table 3. Total Carotenoids (TC), Chlorophyll A and Chlorophyll B

\begin{tabular}{cccc}
\hline Sample & TC $(\mathrm{mg} / \mathrm{mL})$ & Chlorophyll A $(\mathrm{mg} / \mathrm{mL})$ & Chlorophyll B $(\mathrm{mg} / \mathrm{mL})$ \\
\hline PF & $6.6204 \pm 0.85^{\mathrm{a}}$ & $0.023 \pm 0.006^{\mathrm{a}}$ & $0.0324 \pm 0.004^{\mathrm{a}}$ \\
SF & $22.1924 \pm 1.99^{\mathrm{b}}$ & $0.1312 \pm 0.01^{\mathrm{b}}$ & $0.056 \pm 0.008^{\mathrm{b}}$ \\
PM & $9.4558 \pm 0.74^{\mathrm{a}}$ & $0.0414 \pm 0.008^{\mathrm{a}}$ & $0.0692 \pm 0.003^{\mathrm{b}}$ \\
SM & $39.3682 \pm 2.15^{\mathrm{c}}$ & $0.1650 \pm 0.02^{\mathrm{b}}$ & $0.0718 \pm 0.006^{\mathrm{b}}$ \\
\hline
\end{tabular}

Values are presented as mean $\pm \mathrm{SD} ;(\mathrm{n}=3)$. Means with different superscript letters in the same column differ significantly at $\mathrm{P}<0.05$.

from Faridpur. The variation in the content of total carotenoids and chlorophyll can be explained by the differences in growing location and environmental conditions like rainfall, humidity and temperature.

\subsection{Antioxidant activity of Syzygium cumini}

Different mechanisms of actions for antioxidant activities of fruits and vegetables have been recognized widely, such as radical scavenging capacity, inhibition of chain initiation, breakdown of peroxides, the chelating ability of metal ions and reductive capacity of them on metals (Diplock, 1997). In the present work, the antioxidant activity was determined by evaluating the total antioxidant capacity, reducing power and ferrous ion chelating ability of pulp and seed of Jaam. The percentage of inhibition and $\mathrm{IC}_{50}$ values (concentration that is required for $50 \%$ inhibition) were determined.

\subsubsection{Total antioxidant capacity}

Phosphomolybdate assay is an easy and well-known technique based on the reduction of Molybdenum (VI) to Molybdenum (V) by forming phosphate-Molybdenum (V) complex which is green in color with maximal absorption at a wavelength of $695 \mathrm{~nm}$. The total antioxidant capacity differed between two different parts of the fruit (Table 4). Total antioxidant capacity of seed extracts was very high $(438.20-474.47 \mathrm{mg} \mathrm{AAE} / \mathrm{g}$ of dry extract) compared to that found in the pulp extracts of $S$. cumini $(21-34.73 \mathrm{mg} \mathrm{AAE} / \mathrm{g}$ of dry extract). Soong and Barlow (2004) also documented that, seed extracts presented a much greater antioxidant activity than those from the edible portions. Total antioxidant capacity of seed collected from Manikganj (SM) was the highest (474.47 mg AAE/g of dry extract) while the lowest amount of total antioxidant capacity was calculated to be $21 \mathrm{mg}$ AAE per gram of dry extract of pulp collected from Faridpur (PF). The probable explanation of variation for different areas is that the total antioxidant capacity of fruits depends on the growing region and climate conditions that stimulate the biosynthesis of bioactive compounds. Banerjee et al. (2005) previously reported that the total antioxidant capacity of jaam fruit skin was $0.179 \mathrm{mg} \mathrm{AAE} / \mathrm{mg}$ dried skin.

Table 4. Total antioxidant capacity of S. cumini

\begin{tabular}{cc}
\hline Sample & $\begin{array}{c}\text { Total antioxidant capacity } \\
\text { (mg AAE/g of dry extract) }\end{array}$ \\
\hline PF & $21.00 \pm 0.85^{\mathrm{a}}$ \\
SF & $438.20 \pm 4.77^{\mathrm{b}}$ \\
PM & $34.73 \pm 0.93^{\mathrm{c}}$ \\
SM & $474.47 \pm 5.85^{\mathrm{d}}$ \\
\hline
\end{tabular}

Values are presented as mean $\pm \mathrm{SD} ;(\mathrm{n}=3)$. Means with different superscript letters in the same column differ significantly at $\mathrm{P}<0.05$.

\subsubsection{Reducing power}

The seed extracts of $S$. cumini exhibited stronger reducing activity than the pulp extracts. At a concentration of $1000 \mathrm{mg} / \mathrm{L}$, seed extract of SM with an absorbance of 0.9837 showed the highest reducing activity and pulp extract of PF with an absorbance of 0.4205 showed the lowest reducing activity. Results indicate that a greater extent of inhibition was achieved with the increase in concentration in all extracts and showed the effectiveness of the samples in a concentration-dependent pattern (Figure 1). Nevertheless, the reducing power of ascorbic acid with an absorbance value of 1.5426 at a concentration of 1000 $\mathrm{mg} / \mathrm{L}$ was more effective than other experimental samples. The reducing power changes in the following order: ascorbic acid $>\mathrm{SM}>\mathrm{SF}>\mathrm{PM}>\mathrm{PF}$. The report 
of Yildirim et al. (2000) revealed a linear correlation between the reducing power and antioxidant activity of fruit extracts, which supports our present study.

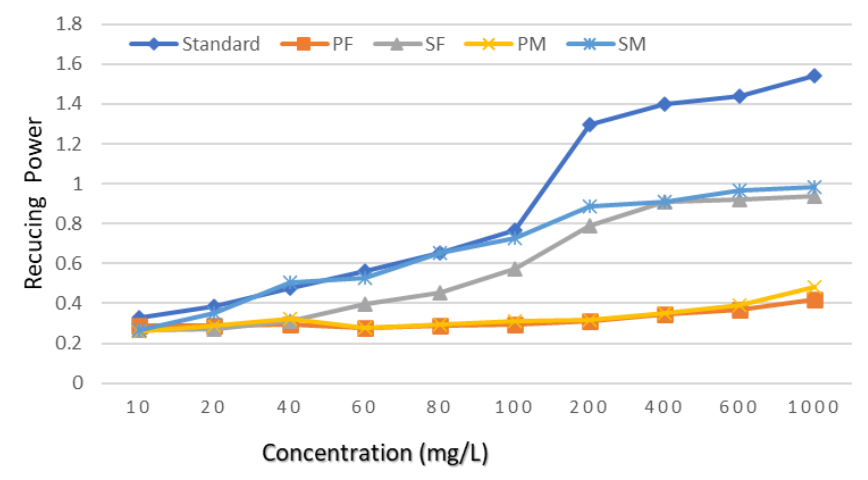

Figure 1. Reducing power of standard and methanolic extracts of $S$. cumini.

\subsubsection{Ferrous ion $\left(\mathrm{Fe}^{2+}\right)$ chelating ability}

Ferrous ion is a highly reactive metal ion, which can act as a catalyst in the oxidative changes of lipids, proteins and other components in the cell (Smith et al., 1992). In several experimental reports, it was found that some chelating agents are very effective to stop or delay the oxidation process because they can act as a secondary antioxidant by forming $\sigma$ bond with metal ion and stabilizing the oxidized form by reducing the redox potential of metal ion (Duh et al., 1999). Ascorbic acid was taken as a standard to study the ferrous ion $\left(\mathrm{Fe}^{2+}\right)$ chelating ability of pulp and seed of Jaam. Ascorbic acid showed maximum $(99.08 \%)$ chelating ability at a concentration of $1000 \mathrm{mg} / \mathrm{L}$ in this experiment and $\mathrm{IC}_{50}$ value was found at $10.25 \mathrm{mg} / \mathrm{L}$. Ferrous ion chelating ability of pulp and seed extracts of $S$. cumini and standard (ascorbic acid) varied remarkably (Table 5). The seed extracts SF and SM and pulp extracts PF \& PM showed $79.31 \%, 59.14 \%, 46.88 \%$ and $60.92 \%$ ferrous ion $\left(\mathrm{Fe}^{2+}\right)$ chelating ability respectively at $1000 \mathrm{mg} / \mathrm{L}$ whereas the standard exhibited $99.08 \%$ ferrous ion $\left(\mathrm{Fe}^{2+}\right)$ chelating ability at the same concentration. Extract prepared from seed showed a greater amount of chelating ability than the pulp extract of $S$. cumini. In comparison with the standard, fruit extracts showed much lower Ferrous Ion $\left(\mathrm{Fe}^{2+}\right)$ chelating ability. Metal ions (e.g. $\mathrm{Fe}^{2+}$ ) play a vital role because they have the ability to catalyze oxidation reaction, which leads to the hydroxyl radical formation and decomposition reactions of hydroperoxide. Chelation of metal ion can delay these processes. Therefore, oxidative damage can be minimizing by reducing the concentration of metal ions. The $\mathrm{IC}_{50}$ value of seed extracts from Faridpur (SF) was lowest $\left(\mathrm{IC}_{50}=368.67 \mathrm{mg} / \mathrm{L}\right)$ and gave the highest ferrous ion chelating ability, followed by $\mathrm{SM}\left(\mathrm{IC}_{50}=657.36 \mathrm{mg} /\right.$ $\mathrm{L}), \mathrm{PM}\left(\mathrm{IC}_{50}=726.91 \mathrm{mg} / \mathrm{L}\right)$ and $\mathrm{PF}\left(\mathrm{IC}_{50}=1156.67 \mathrm{mg} /\right.$ L).

A compound functions as an antioxidant only if it can delay or prevent the oxidation of a substrate by forming a stable complex compound or in any other way and antioxidant free radicals formed after the termination stage should be stable. El-Anany and Ali (2013) found that phenolic compounds found in Jaam caused no histopathological or biochemical changes in the animal organs but the synthetic antioxidant BHT caused some pathologic changes in kidneys and liver. Therefore, the seed extract of $S$. cumini can be efficiently used in food production as a natural source of antioxidants.

\section{Conclusion}

Proximate composition analysis of $S$. cumini revealed that pulp contained significantly $(p<0.05)$ greater amount of minerals than seed but seed contained higher amount lipid, and in the case of protein there was no significant difference between pulp and seed. The methanolic extracts of seed of $S$. cumini possessed significantly $(p<0.05)$ greater amount of carotenoids and total antioxidant capacity compared with methanolic extracts of pulp and subsequently showed significantly $(p<0.05)$ higher ferrous ion chelating ability and had a potent ferric ion reductivity. Thus, this study showed that seeds that are normally discarded is a good source of antioxidant and can be used as an alternative artificial antioxidant in food production.

\section{Conflict of interest}

The authors declare no conflict of interest.

Table $5 . \mathrm{Fe}^{2+}$ chelating ability of standard and methanolic extracts of S. cumini

\begin{tabular}{cccccc}
\hline Concentration $(\mathrm{mg} / \mathrm{L})$ & Standard (ascorbic acid) & PF & SF & PM & SM \\
\hline 100 & $96.06 \pm 0.04$ & $9.04 \pm 0.07$ & $12.87 \pm 0.08$ & $10.78 \pm 0.08$ & $15.99 \pm 0.08$ \\
200 & $97.63 \pm 0.05$ & $10.50 \pm 0.09$ & $28.79 \pm 0.09$ & $19.56 \pm 0.06$ & $24.36 \pm 0.06$ \\
400 & $98.19 \pm 0.08$ & $12.72 \pm 0.05$ & $53.94 \pm 0.07$ & $35.42 \pm 0.07$ & $42.89 \pm 0.09$ \\
600 & $98.56 \pm 0.10$ & $22.36 \pm 0.08$ & $67.91 \pm 0.05$ & $44.93 \pm 0.09$ & $48.47 \pm 0.10$ \\
1000 & $99.08 \pm 0.07$ & $46.88 \pm 0.11$ & $79.31 \pm 0.09$ & $60.91 \pm 0.10$ & $59.14 \pm 0.12$ \\
\hline $\mathrm{IC}_{50}(\mathrm{mg} / \mathrm{L})$ & $0.50 \pm 0.15^{\mathrm{a}}$ & $1169 \pm 5.20^{\mathrm{b}}$ & $367.30 \pm 2.05^{\mathrm{c}}$ & $692 \pm 3.12^{\mathrm{d}}$ & $631.5 \pm 4.11^{\mathrm{e}}$ \\
\hline
\end{tabular}

Values are presented as mean $\pm \mathrm{SD} ;(\mathrm{n}=3)$. Means with different superscript letters in the same row differ significantly at $\mathrm{P}<0.05$. 


\section{Acknowledgment}

The authors thankfully acknowledge Bangladesh Council of Scientific and Industrial Research (BCSIR), Dhaka-1205, Bangladesh for laboratory facilities and the Ministry of Science and Technology, Bangladesh for research grant support.

\section{References}

Akhtar, M., Randhawa, M.A. and Iqbal, Z. (2016). Nutritional, Therapeutic and Food Applications of Jamum (Syzygium cumini). Canadian Journal of Food Sciences and Technology, 1(1), 1-8.

AOAC. (1990). Official Methods of Analysis, $15^{\text {th }}$ Edition. Arlington Virginia, U.S.A.: Association of Official Analytical Chemists, 1094.

AOAC. (2005). Official Methods of Analysis, $18^{\text {th }}$ ed. Gaithersburg, Maryland, U.S.A.: Association of Official Analytical Chemists.

Baliga, M.S., Bhat, H.P., Baliga, B.R.V., Wilson, R. and Palatty, P.L. (2011). Phytochemistry, traditional uses and pharmacology of Eugenia jambolana Lam. (black plum): A review. Food Research International, 44(7), 1776-1789. https:// doi.org/10.1016/j.foodres.2011.02.007

Banerjee, A., Dasgupta, N. and De, B. (2005). In vitro study of antioxidant activity of Syzygium cumini fruit. Food Chemistry, 90(4), 727-733. https:// doi.org/10.1016/j.foodchem.2004.04.033

Benherlal, P.S. and Arumughan, C. (2007). Chemical composition and in vitro antioxidants studies on Syzygium cumini fruit. Journal of the Science of Food and Agriculture, 87(14), 2560-2569. https:// doi.org/10.1002/jsfa.2957

Decker, E.A. and Welch, B. (1990). Role of ferritin as a lipid oxidation catalyst in muscle food. Journal of Agricultural and Food Chemistry, 38(3), 674-677. https://doi.org/10.1021/jf00093a019

Dere, S., Güneş, T. and Sivaci, R. (1998). Spectrophotometric Determination of ChlorophyllA, B and Total Carotenoid Contents of Some Algae Species using Different Solvents. Turkish Journal of Botany, 22, 13-17.

Diplock, A.T. (1997). Will the 'good fairies' please prove to us that vitamin E lessens human degenerative disease? Free Radical Research, 27(5), 511-532. doi.org/10.3109/10715769709065791

Duh, P.D., Du, P.C. and Yen, G.C. (1999). Action of methanolic extract of mung beans hulls as inhibitors of lipid peroxidation and non-lipid oxidative damage. Food Chemistry Toxicology, 37 (11), 10551061. https://doi.org/10.1016/S0278-6915(99)00096-

\section{4}

El-Anany, A.M. and Ali, R.F.M. (2013). Biochemical and histopathological effects of administration various levels of Pomposia (Syzygium cumini) fruit juice as natural antioxidant on rat health. Journal of Food Science and Technology, 50(3), 487-495. https://doi.org/10.1007/s13197-011-0372-6

Gordon, A., Jungfer, E., Silva, B.A., Maia, J.G.S. and Marx, F. (2011). Phenolic constituents and antioxidant capacity of four underutilized fruits from the Amazon region. Journal of Agricultural and Food Chemistry, 59(14), 7688-7699. https:// doi.org/10.1021/jf201039r

Ho, L.H., Noor, A.A.A. and Rajeev, B. (2012). Mineral composition and pasting properties of banana pseudo -stem flour from Musa acuminata X balbisiana cv. Awak grown locally in Perak, Malaysia. International Food Research Journal, 19(4), 14791485.

Leong, L.P. and Shui, G. (2002). An investigation of antioxidant capacity of fruits in Singapore markets.

Food Chemistry, 76(1), 69-75. https:// doi.org/10.1016/S0308-8146(01)00251-5

Noomrio, M.H. and Dahot, M.U. (1996). Nutritive value of Eugenia jambosa fruit. Journal of Islamic Academy of Sciences, 9(1), 9-12.

Oyaizu, M. (1986). Studies on products of browning reaction. The Japanese Journal of Nutrition and dietetics, 44(6), 307-315. https://doi.org/10.5264/ eiyogakuzashi.44.307

Prieto, P., Pineda, M. and Aguilar, M. (1999). Spectrophotometric quantitation of antioxidant capacity through the formation of a phosphomolybdenum complex: specific application to the determination of vitamin E. Analytical Biochemistry, 269(2), 337-341. https:// doi.org/10.1006/abio.1999.4019

Ranganna, S. (1986), Handbook of analysis and quality control for fruit and vegetable products, p. 7-88. New Delhi, India: Tata McGraw-Hill Publishing Company.

Rufino, M.S.M., Alves, R.E., Fernandes, F.A.N. and Brito, E.S. (2011). Free radical scavenging behavior of ten exotic tropical fruits extracts. Food Research International, 44(7), 2072-2075. https:// doi.org/10.1016/j.foodres.2010.07.002

Savikin, K., Zdunic, G., Jankovic, T., Tasic, S., Menkovic, N., Stevic, T. and Dordrvic, B. (2009). Phenolic content and radical scavenging capacity of berries and related jams from certificated area in Serbia. Plant Foods for Human Nutrition, 64(3), 212 -217. https://doi.org/10.1007/s11130-009-0123-2 
Smith, C., Halliwell, B. and Aruoma, O.I. (1992). Protection by albumin against the pro-oxidation action of phenolic dietary components. Food and Chemical Toxicology, 30(6), 483-489. https:// doi.org/10.1016/0278-6915(92)90099-7

Soong, Y. and Barlow, P.J. (2004). Antioxidant activity and phenolic content of selected fruit seeds. Food Chemistry, 88(3), 411-417. https:// doi.org/10.1016/j.foodchem.2004.02.003

Teixeira, C.C., Rava, C.A., Mallman da Silva, P., Melchior, R., Argenta, R., Anselmi, F., Almeida, C.R.C. and Fuchs, F.D. (2000). Absence of antihyperglycemic effect of jambolan in experimental and clinical models. Journal of Ethnopharmacology, 71(1-2), 343-347. https:// doi.org/10.1016/S0378-8741(00)00185-9

Ward, G.M. and Johnston, F.B. (1962). Chemical Methods of plant Analysis, p. 19-20. Canada: Canada Department of Agriculture

Yıldırım, A., Mavi, A., Oktay, M., Kara, A.A., Algur, Ö.F. and Bilaloğlu, V. (2000). Comparison of antioxidant and antimicrobial activities of Tilia (Tilia argentea Desf ex DC), sage (Salvia triloba L.), and Black tea (Camellia sinensis) extracts. Journal of Agricultural and Food Chemistry, 48(10), 50305034. https://doi.org/10.1021/jf000590k

Zhang, L.L. and Lin, Y.M. (2009). Antioxidant tannins from Syzygium cumini fruit. African Journal of Biotechnology, 8(10), 2301-2309. 